\title{
Asinsvadu implanti ar jaunām biomehāniskām īpašībām
}

\author{
Viktorija Kanceviča ${ }^{1}$, Andrejs Lukjančikovs ${ }^{2}$ \\ ${ }^{1,2}$ Dizaina tehnoloğiju institūts, Materiālzinātnes un lietišşāas ķīmijas fakultāte, Rīgas Tehniskā universitāte
}

\begin{abstract}
Kopsavilkums. Izgatavoti asinsvadu implanti, kuru sieniṇās ar aušanas tehnoloğiju iestrādāti tekstila pavedieni ar dažādām īpašībām. Implanti apdares procesā apstrādāti ar bioloğisku šķīdumu. Piedāvātā implanta sieniņu struktūra satur 40 \% dabīgā zīda ķirurğiskos šksēru un audu pavedienus, kas laika periodā uzsūcas organismā un tiek aizvietoti ar pacienta audiem, veidojot protēzi ar maksimāli tuvām rekonstruētā asinsvada (aortas) biomehāniskām īpašībām. Šie raksturlielumi pacienta organismā saglabājas ilgstoši. Šādas struktūras implanti spēj pagarināt pacienta darba mūžu. To apliecina histoloğiskie izpētes dati.
\end{abstract}

Atslēgas vārdi: Asinsvadu implanti, asinsvadu protēzes, asinsvadu mākslīgie aizvietotāji, ateroskleroze, asins plūsmas caurtece, nogulsnējumi asinsvadā, biomehāniskās īpašības, elastības modulis.

\section{IEVADS}

Sirds-asinsvadu slimības ir apzīmējums dažādām kaitēm, piemēram, trombiem, asins izplūdumiem smadzenēs, paaugstinātam asinsspiedienam, stenokardijai un daudzām citām saslimšanām. Kaut gan tās šķiet atšķirīgas, slimībām ir vairākas kopīgas iez̄̄mes un lielākoties viens galvenais cēlonis - asinsvadu pārkalı̧košanās jeb aterolskleroze (9).

Ārstējot šīs slimības problēmas rada pārkalłķotā segmenta aizvietotājs - asinsvadu implants, kura biomehāniskās īpašības neatbilst dabīgo asinsvadu īpašībām. Lai operācija būtu sekmīga, implantam pēc tā pieslēgšanas kopējai asinsvadu sistēmai jāspēj ilgstoši pulsēt, nezaudējot deformatīvās īpašības ass un radiālā virzienā, nodrošinot pacienta fiziologískās funkcijas (10).

Šodien klīnikās lietotie asinsvadu implanti tuvākā vai tālākā pēcoperācijas periodā rada sarežǵîjumus - trombozes līdz $25 \%$ gadījumu, kas saistās ar izstrādājuma sieniņas veidojošiem izejmateriāliem (7).

Statistikas dati liecina, ka asinsvadu pārkaļ̧̧ošanās vai aterosklerozes rezultātā mirušo ir vairāk nekā visos cilvēces karos kopumā. Zinātnieki un medicīnas speciālisti secina, ja nekas nemainīsies, sirds-asinsvadu slimību skaits tuvāko gadu laikā var pieaugt par $36 \%$.

Mūsu zinātniskais darbs ir pamatots uz citu valstu zinātnieku pieredzi (1)-(3).

\section{II.PRAKTISKĀ PIEREDZE}

Kardiovaskulārās saslimšanas rezultātā pacientam samazinās asins plūsmas caurtece vainagartērijās un sirds muskulis netiek apgādāts ar skābekli pietiekošā daudzumā (11)-(13).
Sirds cikla laikā cilvēka asinsvada diametrs mēdz mainīties par 10-12\%, bet tirgū piedāvātie implanti radiālā virzienā spēj deformēties ne vairāk kā 3-5\%.

Asinsvadu implantu aksiālās deformācijas nodrošina protēzes gofrēšana, kas laika gaitā izzūd, un, izstrādājumam pagarinoties, pacienta organismā tas izlokās, intimā veidojas hiperplāzija un protēze pamazām aizsprostojas (4).

Protēze sāk zaudēt aksiālās deformācijas spējas pēc tam, kad sieniņas ir cauraugušas ar saistaudiem, radot asinsvadu implantā spriegumu koncentrāciju.

Mūsdienās asinsvadu slimību sekas likvidē ķirurğiskas iejaukšanās procesā, aizvietojot patologiski skartos asinsvadu posmus ar sintētisku implantu vai speciālu sietinu-stentu (1. att.), ko izgatavo no platīna, kobalta vai hroma un pārklāj ar medikamentiem.

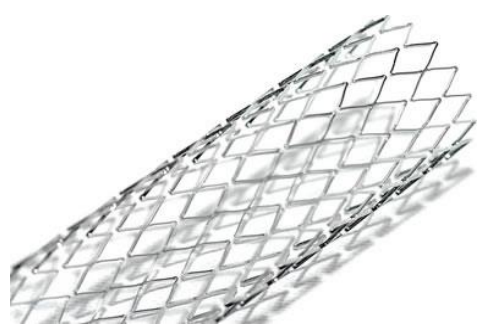

1. att. Stents.

Aizvērtu stentu koronārajā artērijā ievada ar katetru, tad piepūš tajā ievietotu baloninu, atverot stentu un tā neļaujot artērijai saplakt (sk. 2. attēlu).

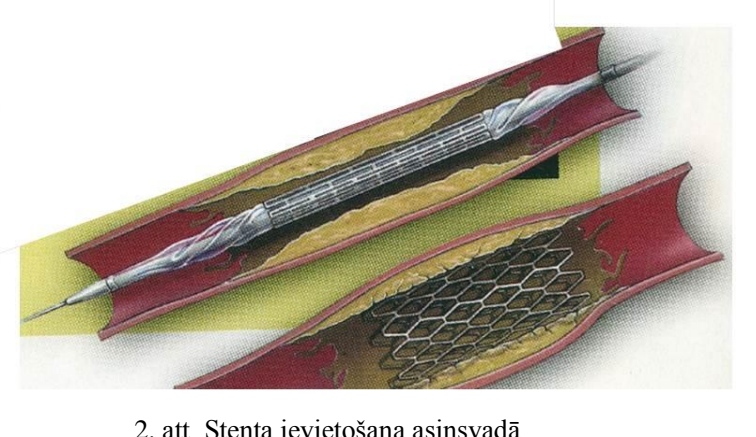

Pacienta organismā medikamenti lēnām izdalās un kavē jaunu nogulsnējumu veidošanos asinsvadā. Tomēr arī stenti nerisina problēmu pilnībā, un sirds-asinsvadu slimības turpina būt galvenais nāves cēlonis pasaulē un arī Latvijā (8). Turklāt stents mūsu klīnikās vidēji maksā 1700 eiro, bet procedūras kopējās izmaksas ir apmēram 4700 eiro. Var būt nepieciešams ievietot pacientam asinsvadu sistēmā vairākas šādas ierīces (5). 
Latvijā asinsvadu paplašināšanas procedūrām gadā tērē aptuveni 24,5 miljonus eiro, tādejādi nodrošinot 6200 pacientu ārstēšanu.

Pētîjumā, (6) ar pīšanas tehnologiju no dabīgā zīda pavedieniem izgatavoti maza diametra $(1,5 \mathrm{~mm})$ asinsvadu implanti un aizvietota žurkas vēdera aorta. Šīs protēzes atšķiras ar optimālām mehāniskām īpašībām un ilgtspējīgu asins plūsmas caurteci, jo dabīgie zīda pavedieni veido elastīgu matricu saistaudu un kaulu mijiedarbību un trombus nepiesaistošu implanta virsmu.

\section{INOVATĪVA SIENIN̦U STRUKTŪRA}

Mēs esam radījuši asinsvadu implantus (sk. 4. attēlu un 5. attēlu) ar tādu sieniņu struktūru, kas spēj ilgstoši nodrošināt biomehāniskās īpašības. To panāk, iestrādājot sienin̄ās izejmateriālus, ar atšksirīgām īpašībām un specifisku aušanas automāta konstrukciju, kā arī ar implanta apdares tehnoloǵiju.

Implanta karkass veidots no trim pavedienu grupām. Katras grupas pavedieni atsevišķi vai savstarpēji sadarbojoties piešķir implantam nepieciešamās funkcijas: nesošo karkasu veido poliestera šķēru pavedieni $(20 \%)$, kas uztur protēzes sieniņu struktūru un organismā neuzsūcas, karkasa nepieciešamo radiālo un aksiālo deformāciju nodrošina šksēros un audos iestrādātie poliuretāna pavedieni $(40 \%)$, austās struktūras audos un šksēros integrētie dabīgā zīda ķirurğiskie pavedieni (40 \%) satur proteīna šķiedras (sk. 3. attēlu), cilvēka organismam nepieciešamās aminoskābes un aktivizē vielmainu.

Lai novērstu infekcijas riskus, noaustos implantus sterilizē destilēta ūdens tvaikos, vakuumā piesūcina ar želatīna, glicerīna, mildronāta un venescina šḳ̂̄dumu, kas veido sienin̄ās elastīgas membrānas un noklāj tās ar deformēties spējīgu matricu.

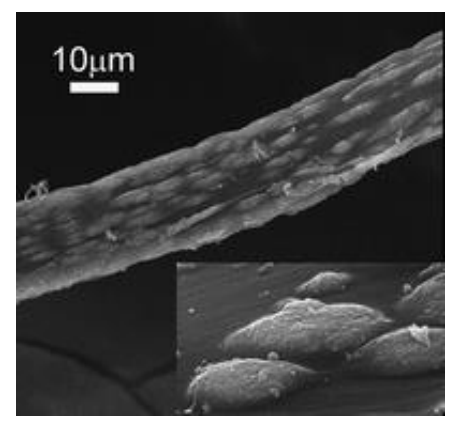

3. att. Dabīgā zīda šķiedra mikroskopā.

Rezultātā tiek novērsta sieninu caurlaidība pēc protēzes pieslēgšanas kopējai asinsvadu sistēmai. Divu vai trīs gadu laikā pēc ķirurǵiskās iejaukšanās dabīgie zīda pavedieni organismā pakāpeniski uzsūcas, bet to vietā protēzes sieniņās matricas līmenī ieaug dzīvie audi.

Kopumā šāda tehnoloǵija ļauj ilgtermiņā saglabāties implanta elastībai, nodrošinot normālu asins plūsmas caurteci bez restenozes (atkārtotas asinsvada sašaurināšanas). Tas liecina, ka dabīgā zīda ķirurgísko pavedienu iekḷaušana implanta sieniņu struktūrā ḷauj biomehāniskās īpašības pielāgot organisma asinsvadu sistēmas īpašībām.

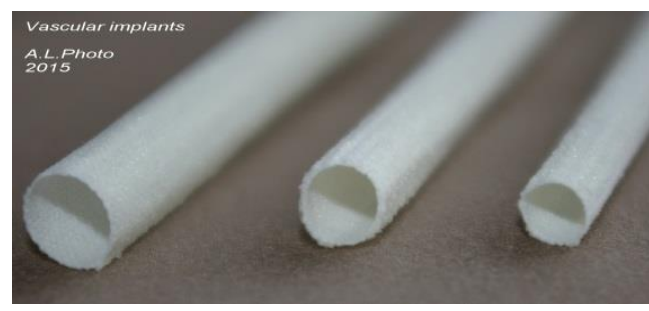

4. att. Lineārie asinsvadu implanti.

Asinsvadu implanta inovatīvā sieniņu struktūra iztur spriegumu aploces virzienā $\sigma=2,30-2,40 \mathrm{MPa}$, deformējoties par $\varepsilon=43 \%$, bet ass virzienā, attiecīgi, $\sigma=3,20 \mathrm{MPa}$, $\varepsilon=33 \%$.

Galvenais biomehānisko īpašību raksturlielums - elastības modulis izgatavotiemasinsvadu implantiem aksiālā virzienā $\mathrm{E} 1=19,50 \mathrm{MPa}$ un radiālā virzienā $\mathrm{E} 2=5,10 \mathrm{MPa}$.

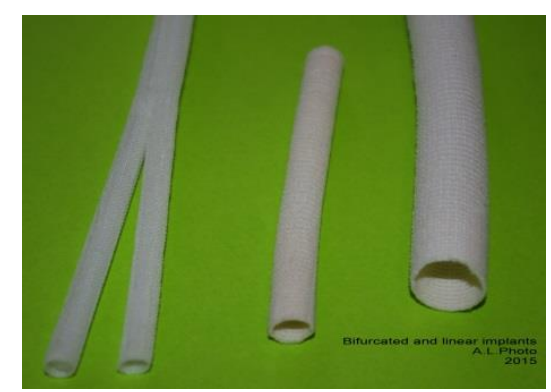

5. att. Bifurkācijas un lineārie asinsvadu implanti.

Histologiskajos suniem implantēto protēžu izmeklējumos konstatēts, ka implanti pēc laika ir caurauguši ar saistaudu šūnām un šķiedrām, labi saglabājot elastību, kas liecina, ka piedāvātās struktūras implanti spēj ilgstoši funkcionēt organismā, nodrošinot hemodinamiskos procesus un adekvātu asins plūsmu sirds muskuļa apgādei ar skābekli, saglabājot stabilas biomehāniskās īpašības, tajā skaitā elastību aksiālā un radiālā virzienā. Turpmākajos pētījumos nepieciešama jaunās struktūras implantu izpēte in vivo pacientiem.

\section{LITERATŪRAS SARAKSTS}

1. Craig, K., et al. Anti-Thrombogenic Modification of Small-Diameter Microfibrous Vascular Grafts. Arteriosclerosis, Thrombosis, and Vascular Biology - Journal of the American Heart Association. 30, 2010, pp. 1621-1627.

2. Sato, M., et al. Small-Diameter Vascular Grafts of Bombyx Mori Silk Fibroin Prepared by a Combination of Electrospinning and Sponge Coating. Material Letters. vol. 64, Issue 16, 2010, pp. 1786-1788. http://dx.doi.org/10.1016/j.matlet.2010.05.024

3. Nakazawa, Y., et al. Development of Small-Diameter Vascular Grafts Based on Silk Fibroin Fibres from Bombyx Mori for Vascular Regeneration. Journal of Biomaterials Science. vol. 22, 2011, pp. 195 206. http://dx.doi.org/10.1163/092050609X12586381656530

4. Patrzyk, M., Hoene, A., Jarchow, R., et al. Time Course of Fibronectin in the Peri-Implant Tissue and Neointima Formation After Functional Implantation of Polyester-Based Vascular Prostheses With Different Porosity in Pigs. Biomed Materials. 2010, vol. 5, no. 5. http://dx.doi.org/10.1088/1748-6041/5/5/055003

5. Spring̣e, I. Galma kardiologs. Re: Baltica (pētnieciskās žurnālistikas centrs) [tiešsaiste]. [skatīts 12.03.2014.]. Pieejams: http://www.rebaltica.lv/lv/petijumi/veseliba_latvija/a/1069/galma_kardi ologs.html

6. Enomoto, S., Sumi, M., Kajimoto, K., et al. Long-Term Patency of SmallDiameter Vascular Graft Made from Fibroin, a Silk-Based Biodegradable Material. Journal of Vascular Surgery. 2010, vol. 51, Issue 1, pp. 155164. http://dx.doi.org/10.1016/j.jvs.2009.09.005 
7. Lukjančikovs A., Kantsevicha V., Auzāns A. Aušanas tehnoloǵiskā procesa parametru ietekme uz inovatīvas struktūras aortas implanta biomehāniskām īpašībām. RTU zinātniskie raksti „,Materiālzinātne. Tekstila un apgēerbu tehnologija”, 5. sēj., 2010, 17.-20. lpp.

8. Galvenais nāves cēlonis Latvijā ir sirds un asinsvadu slimības. Nacionālā informācijas aǵentūra LETA. [tiešsaiste]. [skatīts 14.07.2013.]. Pieejams: http://www.delfi.lv/news/national/politics/galvenais-naves-celonislatvija-ir-sirds-un-asinsvadu-slimibas.d?id=43481023

9. Informē, izglīto un iedvesmo veselīgai dz̄̄vei. LR Veselības Ministrija. [tiešsaiste]. Pieejams: http://www.vesels.lv/uzturs/ieteikumi-darzenu-unauglu-lietosanai-uztura.html.

10. Polymeric Biomaterials. Structure and Function. vol. 1. p. 578. Editor: Popa V., Founding Editor: Dumitriu S.: ISBN:978-1-4200-9470-1.

11. Kas jāzina par Jūsu sirds mazspējas terapijas sistēmu. Sirds ritma terapija. Brošūra pacientiem. [tiešsaiste]. BIOTRONIK SE \& Co. KG, Berlin, Germany. Piejams: http://www.biotronik.com/files/B0075DCEE129CF81C1257B81002535 FA/\$FILE/Patientbrochure_CRT_LV.pdf.

12. Sekas sāpēm sirds apvidū...Infarkts. Latvijas veselības portāls medecine.lv. [tiešsaiste]. [skatīts 27.06.2012.]. Pieejams: http://www.medicine.lv/raksti/sekas-sapem-sirds-apvidu-infarkts.

13. Kāpēe sirds paplašinās, un kā to ārstēt? Latvijas invazīvās kardiologijas attīstības biedrība. Kardiologija.lv. [tiešsaiste]. [skatīts 16.09.2014.]. Pieejams: http://www.kardiologija.lv/lv/pacientiem/sirds-slimibas/kapecirds-paplasinas-un-ka-to-arstet-la-lv/

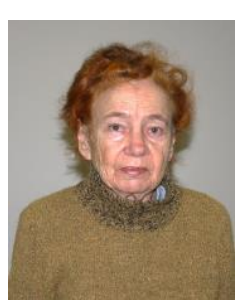

Viktoriya Kancevicha, Dr. habil. sc. ing., is a leading researcher at Riga Technical University. Her research interests are manufacture of vascular implants and research of their properties. E-mail: Viktorija.Kancevica@rtu.lv

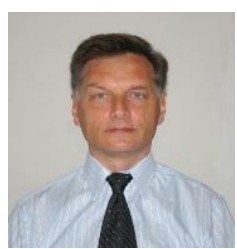

Andreys Lukyanchikovs,

Dr.sc.ing. is a leading researcher at Riga Technical University.

His research are the manufacture of vascular implants and research of their properties. E-mail: Andrejs.Lukjancikovs@rtu.lv

\section{Viktoriya Kancevicha, Andreys Lukyanchikovs. Vascular implants with new biomechanical properties}

New woven vascular implants were developed during the implementation of this research work. Synthetic and natural textile yarns were integrated into the walls of these implants. These yarns had different source properties. Prostheses were manufactured by weaving. These implants were further processed by special biological solution in the process of finishing. The proposed wall structure of synthetic woven prostheses contains $40 \%$ warp and weft natural silk yarn, which dissolves over a period in the organism of the patient and gradually is replaced by living tissues. Biomechanical properties of the new prosthesis were maximally close to the properties of a reconstructed natural blood vessel (aorta). These properties in an organism of the patient may persist for a long time. Implants with such a structure help to increase the duration of physical activity of the patient. This was confirmed by histological studies.

Виктория Канцевича, Андрей Лукьянчиков. Импланты кровеносных сосудов с новыми биомеханическими свойствами

В процессе реализации данной научно-исследовательской работы были предложены тканые импланты кровеносных сосудов, в стенки которых были интегрированы синтетические и натуральные текстильные нити, обладающие различными исходными свойствами. Протезы были изготовлены методом ткачества. В процессе отделки данные импланты были дополнительно обработаны специальным биологическим раствором. Предложенная структура стенки синтетического тканого протеза содержит $40 \%$ основных и уточных нитей натурального шелка, которые в течение определенного периода рассасываются в организме пациента и постепенно замещаются живыми тканями. Исходя из этого, данный протез по своим биомеханическим свойствам является максимально приближенным к реконструированному натуральному кровеносному сосуду (аорте). Эти свойства в организме пациента сохраняются длительное время. Импланты такой структуры могут значительно увеличить продолжительность физической активности пациента, что было подтверждено данными гистологических исследований. 